\title{
「破断履歴の相似則」の検証 \\ VERIFICATION OF SIMILITUDE LAW OF PRE-FRACTURE HYSTERESES
}

\author{
桑村 仁*, 高木直 人** \\ Hitoshi KUWAMURA and Naoto TAKAGI
}

\begin{abstract}
A hypothesis named 'similitude law of pre-fracture hystereses' has been applied to estimation of deformation capacity prior to brittle fracture of any type of steel connections from a single curve which describes the relationships between amplitude and accumulation of plastic deformation. However, this method of capacity estimation is open to criticism, because the basic curve was derived only from a limited set of test data, in other words, the similitude law has not yet been proved. This paper is devoted to verifying the law by means of four independent series of experimental data. It is found that the relationships between amplitude and accumulation of plastic deformation governed by ductile as well as brittle fracture can be represented by a single curve with a satisfactory degree of reliability.
\end{abstract}

Keywords : brittle fracture, ductile fracture, cyclic loading, ductility, earthquake resistance 脆性破壊, 延性破壊, 繰返し荷重, 塑性変形能力, 耐震性能

\section{1 「破断履歴の相似則」という仮説}

「破断履歴の相似則」というのは, 文献 4) で初めて提唱された次 のように表現される仮説である。

「材料や溶接の条件が異なる鋼部材 $\mathrm{A}$ と B が，それぞれ一定の 塑性率振幅 $\mu_{p A}, \mu_{p B}$ で繰返し負荷を受けて脆性破断するまでのサ イクル数 $N_{f}$ が等しければ, 任意の係数を乗じた塑性率振幅 $c \mu_{p A}$, $c \mu_{p B}$ に対して A と B は等しいサイクル数 $N_{f}^{\prime}$ で脆性破断する。」 この関係をグラフで説明したのが図一 1 で, 降伏後の塑性変形過 程で破断する場合を対象としている。図の上段には塑性率振幅 $\mu_{p A}$, $\mu_{p B}$ によって部材 $\mathrm{A}$ と B がともに $N_{f}=5.3$ で破断し, 中段には係数

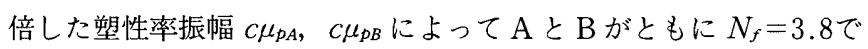
破断方る例を示している。この例では $c>1$ である。なお， $\mu_{p A}<\mu_{p B}$ であるので，Bのほうが Aより破断に対して優れている。

図一2 を用いて記号の定義をしておく。先ず, 塑性率振幅 $\mu_{p}$ は次 のように定義される。

$$
\mu_{p}=\frac{\Delta \delta_{p}}{\delta_{p}}
$$

ここで, $\Delta \delta_{p}(\mathrm{~mm})$ は変位振幅 (片振幅) $\Delta \delta$ から弾性成分 $\Delta \delta_{e}$ を 除いた塑性成分のみの振幅である。実験を行うと, 変位振幅 $\Delta \delta$ を一 定に制御しても $\Delta \delta_{p}$ はサイクル毎にわずかながら変化するので, 次 のように破断直前のサイクルまでの平均値とする。

$$
\Delta \delta_{p}=\frac{\Delta \delta_{p 1}+\Delta \delta_{p 2}+\cdots+\Delta \delta_{p n}}{n}
$$

図一 2 の場合には $n=4$ である。 $\delta_{p}(\mathrm{~mm})$ は全塑性耐力における 弾性変形である。 $\delta_{p}$ は基準化のために用いるので, どのような方法
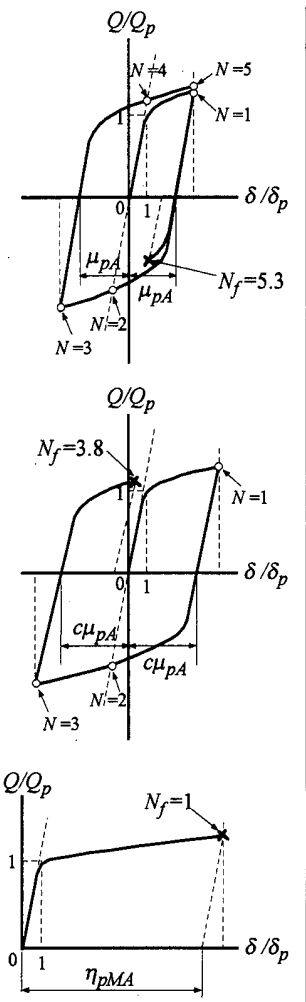

(a) 部材 $\mathrm{A}$
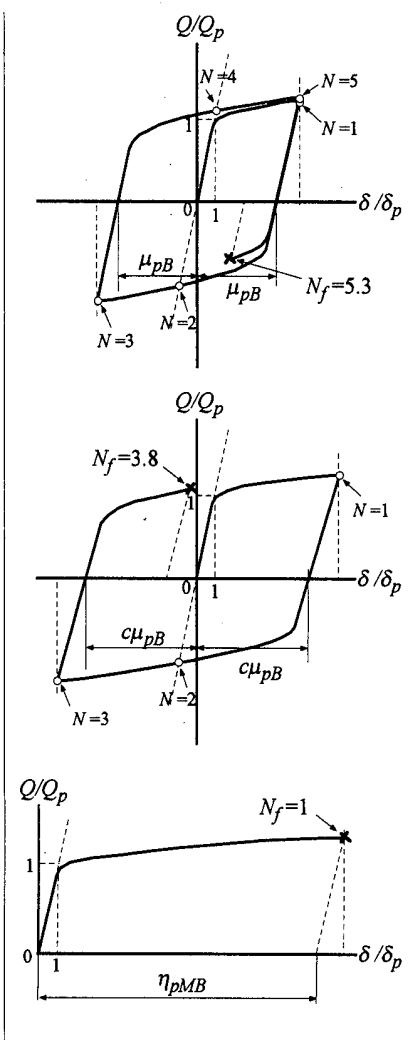

(b) 部材 $\mathrm{B}$

\section{図一 1 破断履歴の相似則の説明図}


で算定しても破断履歴の相似則には影響を与えないが，ここでは， 図一2に図解してあるゼネラルイールド法を用い初期載荷曲線から 算定するものとする。

次に, 繰返しサイクル数 $N$ は, 通常の定義と異なり, 塑性率振幅

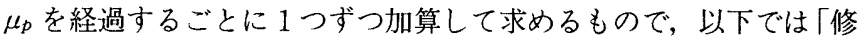
正サイクル数」と呼ぶことにする。破断までの累積塑性率を $\eta_{p}$ とす ると, 破断までの修正サイクル数 $N_{f}$ は次式で定義され, 整数值とは 限らない。

$$
N_{f}=\frac{\eta_{p}}{\mu_{p}}
$$

ここで, $\eta_{p}$ は, 破断までの累積塑性変形を $\delta_{p}$ で除したもので, 図 一 2 に示した記号を用いると次のように定義される。

$$
\eta_{p}=\frac{\Delta \delta_{p 1}+\Delta \delta_{p 2}+\cdots+\Delta \delta_{p, n+1}}{\delta_{p}}
$$

破断時の $\Delta \delta_{p, n+1}$ についても弾性変形を除くものとし, 初期剛性 にしたがって破断点から弾性除荷が起こるとして弾性変形を算定す る。

さて，変位振幅が大きくなると，前出図一 1 の下段に示すように 第 1 サイクルの載荷すなわち単調載荷の途中で破断する。このとき には, $N_{f}=1$ となるので, (3)式から $\mu_{p}=\eta_{p}$ となる。このときの塑性 率 $\left(=\right.$ 累積塑性率)を $\eta_{P M}$ で表すことにする。 $\eta_{P M}$ は次式で定義され る。

$$
\eta_{p M}=\frac{\delta_{p M}}{\delta_{p}}=\frac{\delta_{f}}{\delta_{p}}-\frac{Q_{f}}{Q_{p}}
$$

ここで, $\delta_{f}, Q_{f}$ は図一 2 に示すように破断時の変形と荷重で, $Q_{p}$ はゼネラルイールド法による全塑性荷重である。

冒頭に述べた破断履歴の相似則が単調載荷まで拡張できるとしよ j。すると，塑性率振幅 $\mu_{P A}, \mu_{P B}$ を単調載荷での破断塑性率 $\eta_{P M A}$, $\eta_{P M B}$ に置き換えることができ， $c=\mu_{p} / \eta_{P M}$ となることに注意する と，相似則は次のように言い表すことができる。

「破断までの修正サイクル数 $N_{f}$ は， $\mu_{p} / \eta_{p M}$ だけで決まり，材料 や溶接の条件は無関係である。」

これは, 次のように数式で表示され, 関数 $f_{1}, f_{2}, f_{3}$ は材料や溶接 には関係しない単一な関数であることを相似則は主張している。

$$
N_{f}=f_{1}\left(\frac{\mu_{p}}{\eta_{p M}}\right)
$$

あるいは，(3)式の関係を用い， $\mu_{p}$ を消去して $\eta_{p} に$ 置き換えると，

$$
f_{2}\left(\frac{\eta_{p}}{\eta_{p M}}, N_{f}\right)=\text { const }
$$

同様に，(3)式を用い， $N_{f}$ を消去して $\eta_{p}$ に置き換えると，

$$
f_{3}\left(\frac{\mu_{p}}{\eta_{p M}}, \frac{\eta_{p}}{\eta_{p M}}\right)=\text { const }
$$

が導かれる。これら 3 つの式は(3)式の関係により互換性のある等価 な式である。なお，単調載荷における破断デー夕がない場合には， 上式の $\eta_{P M}$ は仮想の值と考えてもよい。

以上が「破断履歴の相似則」と呼ばれるものである。しかし，こ れは仮説であって，まだ証明されていない。本論は，4シリーズの 独立な実験デー夕を使って，この仮説を実証しようと試みたもので ある。

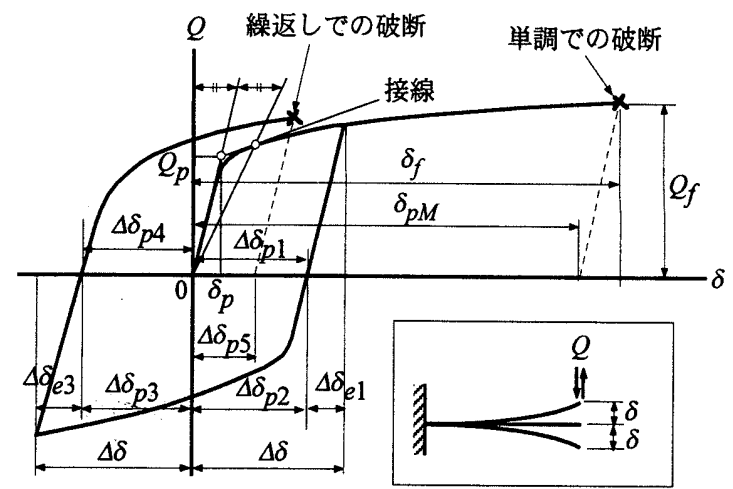

図一2＼cjkstart記号の説明図

\section{2 「破断履歴の相似則」の工学的意義}

もし，破断履歴の相似則が成立し，それを支配する関数 $f$ がわか れば，次のことがいえる。

「任意の材料と溶接の条件でつくられた鋼部材が, ある一定振幅 $\mu_{p}$ での繰返し載荷によって破断するまでの修正サイクル数 $N_{f}$ または累積塑性率 $\eta_{p}$ がわかれば，(6)，(7)，または(8)式を使って任 意の一定振幅における破断までの修正サイクル数または累積塑性 率を算定することができる。」

関数 $f$ は, 後で紹介する大形 Box 梁の脆性破断実験に基づいて 次式が提案されている21

$\mu_{p}, \eta_{p M}, N_{f}$ を使った(6)式に関しては,

$$
\begin{aligned}
& N_{f}=\frac{\eta_{p M}}{\mu_{p}} \cdot\left(\frac{\eta_{p M}}{\mu_{p}}-1\right)^{2 / 3} \frac{\eta_{p M}}{\mu_{p}} \geq 2 \text { のとき } \\
& N_{f}=\frac{\eta_{p M}}{\mu_{p}} \quad \frac{\eta_{p M}}{\mu_{p}}<2 の と き
\end{aligned}
$$

$\eta_{p}, \eta_{p M}, N_{f}$ を使った(7)式に関しては,

$$
\begin{array}{ll}
\left(\frac{\eta_{p}}{\eta_{p M}}\right)^{5 / 2}+\left(\frac{\eta_{p}}{\eta_{p M}}\right)=N_{f} & N_{f} \geq 2 \text { のとき } \\
\frac{\eta_{p}}{\eta_{P M}}=1 & N_{f}<2 \text { のとき }
\end{array}
$$

$\mu_{p}, \eta_{p}, \eta_{p M}$ を使った(8)式に関しては,

$$
\begin{array}{ll}
\frac{\eta_{p}}{\eta_{p M}}=\left(\frac{\eta_{p M}}{\mu_{p}}-1\right)^{2 / 3} & \frac{\mu_{p}}{\eta_{p M}} \leq \frac{1}{2} \text { のとき } \\
\frac{\eta_{p}}{\eta_{p M}}=1 & \frac{\mu_{p}}{\eta_{p M}}>\frac{1}{2} \text { のとき }
\end{array}
$$

このように定式化された「破断履歴の相似則」は，次のような工 学的意義を持つものとなるであろう。

1 ) 試験体数の削減：破断までの累積塑性変形能力は振幅の影響を 受けることが知られており，振幅に応じた性能を調べるにはかな クの数の試験体を必要とする。また，脆性破断の実験では試験体 サイズが大きくなるので実験費用の負担も大きい。ところが，相 似則を使えば，1つの振幅で行った実験のデータから他の振幅で の破断性能が評洒可能となるので, 調査の経済的効率が著しく改 善できる。

2 ）実験データの信頼性確認：破断現象は大きなばらつきを伴うの で, 少数の実験データではその信頼性を判定できないことが多い。 しかし，相似則の方程式から得られる予測值と実験デー夕を比較 
することによって，データの信頼性を確認することができる。

「破断履歴の相似則」は，まだ実証されていないが，その有用性が 極めて高いこと，およびそれに対する反証がないことから，これを

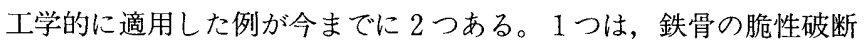
性能に及ぼす各種要因の分析に利用されている(5),6)。そこでは, 繰返 し履歴過程で脆性破断したものを単調載荷での破断変形に換算して 性能を比較し, 脆性破断に対する板厚や材料䩲性, 溶接入熱の影響 を分析している。もう1つは，脆性破断を防止する設計技術の枠組 の構築に用いられている7),8),9)。そこでは, 直下型地震と海洋型地震 の入力の違いがもたらす異なった変位振幅を考慮して破断性能が評 価されている。

このようなことから，「破断履歴の相似則」を実証することは，工 学的な応用, 特に耐震設計の面から急務といえる。

\section{3 検証の方法}

\section{1 検証に用いた実験データ}

「破断履歴の相似則」の検証にあたって，4組の独立した実験デ一 夕を用いた。その実験概要を図一 3 に，実験変数等を表一 1 にまと
めてある。以下, 各シリーズの実験について説明を加えるが, 詳細 については紙面の都合上, 当該参考文献に譲ることにする。ただし, 材料特性については表一 2 に整理しておいた。

・第 1 シリーズ (大形 Box 梁の曲げ実験2)：このシリーズの特徴 は, 実大サイズであること, および単調載荷と繰返し載荷で脆性 破断が再現されていることである。2 種類の材料（低鞀性材と高 靯性材）が使われているので，これが相似則の検証に役立つ。な お, 脆性破壊に関わる試験温度は低温窒素ガスの噴射により $0{ }^{\circ} \mathrm{C}$ に制御されている。

・第 2 シリーズ(小形角棒の曲げ実験) : このシリーズの特徵は, 小 さな試験体サイズで脆性破断が再現されていることである。した がって, 第 1 シリーズに対してサイズが異なる点が相似則の検証 に役立つ。なお, 単調載荷では脆性破断ではなく, 耐力の劣化過 程で脆性破断する擬似脆性破断となっていることに注意が必要で ある。試験温度は室温である。

・第 3 シリーズ (小形丸棒の引張圧縮実験 $\left.{ }^{1}\right)$ ：このシリーズでは, 2 種類の材料（低勒性材と高勒性材）および 3 種類のノッチ形状 (V 形, U 形, O 形) が使われている。なお，破断形式は擬似脆性
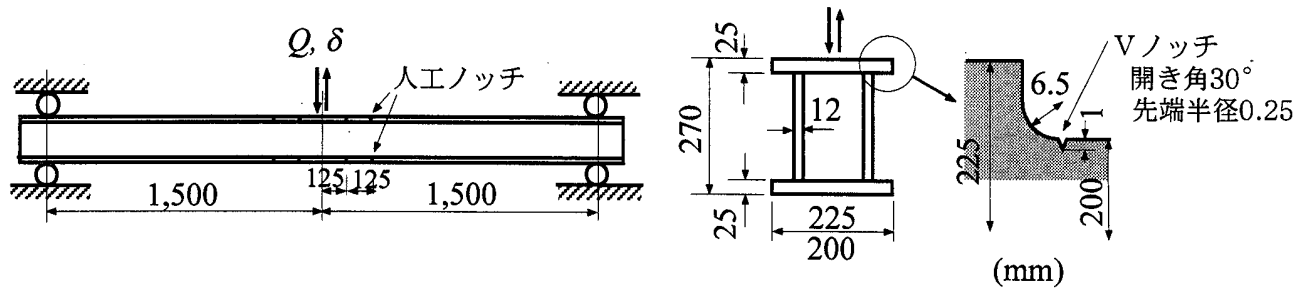

(1) 第 1シリーズ（大形Box 梁の曲げ）
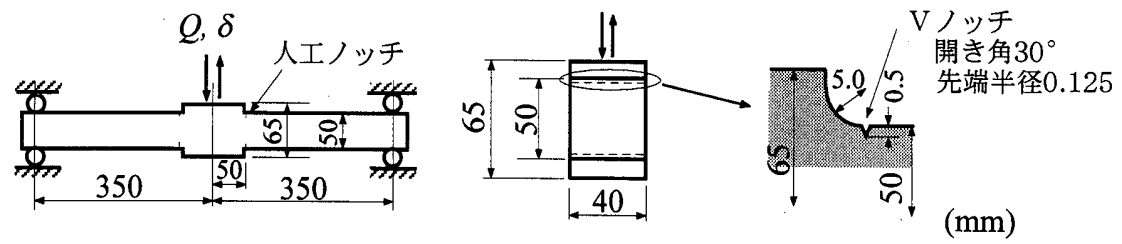

（2）第 2シリーズ (小形角棒の曲げ $)$
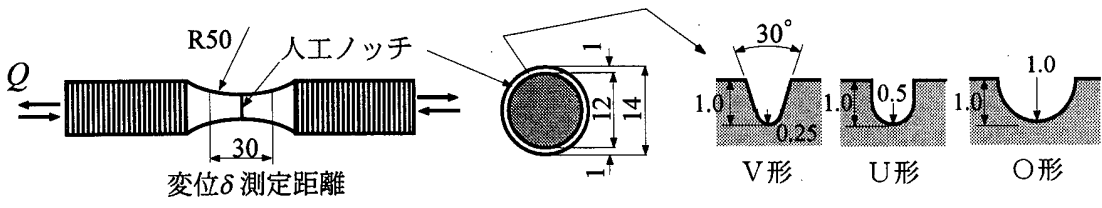

$(\mathrm{mm})$

(3) 第 3 シリーズ (小形丸棒の引張圧縮)
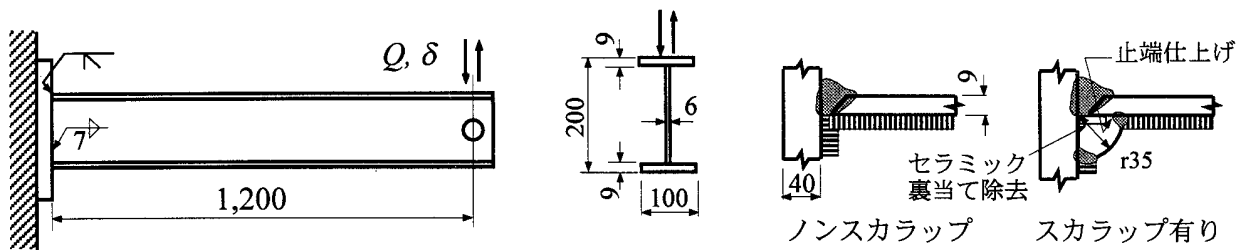

(4) 第 4 シリーズ（小形溶接 $\mathrm{H}$ 梁の曲げ）

図一 3 実験概要 
破断であるので，破断履歴の相似則が適用できる破断モードにつ いても知見が得られる。なお，試験温度が一定值に制御できてい ないが, 結果的には破断変形と温度の相関が認められなかったの で，温度の影響は無視できる。

・第 4 シリーズ(小形溶接 $\mathrm{H}$ 梁の曲げ実験3)：このシリーズでは, 破断位置（片持ち梁の固定端）が溶接接合となっている。2 種類 の鋼材 (HT600, SM490), 3 種類の接合形式（スカラップの有, 無, 仕上), および 2 種類の溶接姿勢 (下向き, 立向き) が使われ ている。ただし，フランジ厚 $(9 \mathrm{~mm})$ が薄いため，単調載荷では 破断せず局部座屈しているものがあること，および破断した試験 体の破断形式は延性破断であることに注意が必要である。試験温 度は室温である。

上で述べた脆性破断，擬似脆性破断，延性破断という破断形式(破 断モード）をここでは次のように分類する。なお，「破壊」と「破断」 を区別し，破壞は連続体としての材料に分離が起こることを指し， 破断は破壊が進行して構造力学的に荷重の伝達能力をほとんど喪失 することをいう。本論では破断を対象としている。

・脆性破断(図一 4 (a), 図一5(a))：耐力劣化を伴わないで破断する。 破断の起点には延性き裂が観察されるが，延性き裂の範囲が全断 面に占める割合が小さいので，耐力が低下寸ることなく耐力上昇 中に破断する。破断は脆性破壊によるもので，その破面は板の面 に垂直である。

・擬似脆性破断 (図一 4 (b), 図一 5 (b))：耐力劣化を伴って破断する。 先行発生する延性き裂の範囲が全断面に占める割合が大きくなり 緩やかな耐力低下が始まる。劣化過程で延性き裂が限界き裂蓄 ズに達して脆性破断する。

- 延性破断(図一 4 (b)，図一 5 (c))：耐力劣化を伴って破断する。擬 似脆性破断と異なるのは, 延性き裂が脆性破壊に転化せずそのま ま延性破断となることである。したがって，断面全体に明瞭な絞 クが観察される。
この3つの破断モードは寸法効果による連続的なものであると考 えられる。実大の厚肉部材では脆性破断しても，小さい試験片では 擬似脆性破断あるいは延性破断にモードが遷移する傾向がある。こ れは, 小形試験片では先行発生する延性き裂の面積が全断面積に占 める割合が大きくなるためである。「破断履歴の相似則」は，もとも と脆性破断に対して提唱されたものであるが，ここでは，擬似脆性 破断と延性破断も含めて検討することにする。

\section{2 検証の方法}

「破断履歴の相似則」の検証は，前出(9)，(10)または(11)式が材料や溶 接条件にかかわらず成立することを確認することである。(9)，(10)， (11)式は(3)式の関係により互いに等価であるので，ここでは(11)式の成 立性を検討することとする。すなわち，部材が破断するまでの塑性 率振幅 $\mu_{p}$ と累積塑性率 $\eta_{p}$ の関係が, 材料や溶接条件にかかわらず (11)式に従うということを確認する。

そのためには，まず，(11)式中の基本変数 $\eta_{p M}$ を回帰分析によって 求める必要がある。ここでは, 次のように最小 2 乗法を用いて推定 する。式の表示を簡単にするために, $x_{i}=\frac{\mu_{p i}}{\eta_{p M}}, y_{i}=\frac{\eta_{p i}}{\eta_{p M}}$ とおくと, 実験值 $\mu_{p i}, \eta_{p i}$ を代入して得られる $\left(x_{i}, y_{i}\right)$ と(11)式による予測值の 差 $\Delta y_{i}$ は

$$
\Delta y_{i}=\left\{\begin{array}{lll}
y_{i}-\left(\frac{1}{x_{i}}-1\right)^{2 / 3} & \text { for } & x_{i} \leq \frac{1}{2} \\
y_{i}-1 & \text { for } & x_{i}>\frac{1}{2}
\end{array}\right.
$$

表一1 本論文で用いた実験データ

\begin{tabular}{|c|c|c|c|c|c|c|}
\hline 寨験シリーズ & 試駿体形状 & 載荷方法 & 溶接 & 実験衮数 & 破断モ一ト & 樲駿機関 \\
\hline 第 1 シリーズ & $\begin{array}{c}\text { 大形 } \\
\text { Box形面 }\end{array}$ & 曲げ & なし & 低勒性林 & 脃性破断 & \begin{tabular}{|l} 
住灰金䲩 \\
文塥2)
\end{tabular} \\
\hline 第 2シリーズ & $\begin{array}{l}\text { 小形 } \\
\text { 矩形断面 }\end{array}$ & 曲岾 & なし & 低䩘性材 & 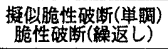 & 東京大学 \\
\hline 第 3 シリーズ & $\begin{array}{l}\text { 小形 } \\
\text { 円形断面 }\end{array}$ & 引張圧縮 & なし & 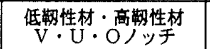 & 擬似脆性破断 & $\begin{array}{l}\text { 東京大学 } \\
\text { 文献1) }\end{array}$ \\
\hline 第 4 シリーズ & 溶接H形 & 曲活 & 有り & 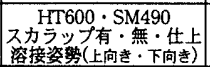 & 延性破断 & 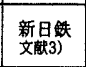 \\
\hline
\end{tabular}

表一 2 材料特性

\begin{tabular}{|c|c|c|c|c|c|c|c|c|c|c|}
\hline 実験シリーズ & $\begin{array}{l}\text { 材料 : 板厚 } \\
\text { (規格) }\end{array}$ & 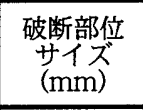 & $\begin{array}{c}\text { 引張試験片 } \\
\text { 採取位置(規格) }\end{array}$ & $\begin{array}{c}\text { 降伏強さ } \\
\sigma y \\
(\mathrm{~N} / \mathrm{mm} 2) \\
\end{array}$ & $\begin{array}{c}\text { 引張強さ } \\
\sigma u \\
(\mathrm{~N} / \mathrm{mm} 2) \\
\end{array}$ & $\begin{array}{l}\text { 降伏比 } \\
\sigma y / \sigma u\end{array}$ & $\begin{array}{l}\text { 一様伸び } \\
\varepsilon u(\%)\end{array}$ & $\begin{array}{c}\text { シャルどー試 } \\
\text { 験片探取愠 } \\
\text { (JIS-4号) }\end{array}$ & 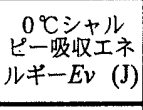 & $\begin{array}{l}\text { シャルピー } \\
\text { 破面逼移温 } \\
\text { 度 }\end{array}$ \\
\hline \multirow{6}{*}{$\begin{array}{c}\text { 第 } 1 \text { シリーズ } \\
\text { (大形Box梁の脆性破断) }\end{array}$} & \multirow{3}{*}{$\begin{array}{c}\text { 低靭性・ t } 25 \\
(\mathrm{SN} 490)\end{array}$} & \multirow{6}{*}{$\begin{array}{c}\text { フランジ } \\
\text { t25 } 2 \mathrm{~B} 225 \\
\mathrm{t} 25 \times \mathrm{B} 200\end{array}$} & \begin{tabular}{|l|} 
全厚 (JIS-5号) \\
\end{tabular} & 332 & 562 & 0.59 & 18 & - & - & - \\
\hline & & & t/4 (JIS-A2号改) & 342 & 568 & 0.60 & - & $t / 4$ & 36 & 34 \\
\hline & & & t/2 (JIS-A2号改) & 317 & 572 & 0.55 & - & $t / 2$ & 19 & 43 \\
\hline & \multirow{3}{*}{$\begin{array}{l}\text { 高勒性・ t25 } \\
\text { (SN490) }\end{array}$} & & \begin{tabular}{|l|} 
全厚 (JIS-5号) \\
\end{tabular} & 332 & 522 & 0.64 & 19 & - & - & - \\
\hline & & & $\mathrm{t} / 4$ (JIS-A2号改) & 362 & 558 & 0.65 & - & $t / 4$ & 155 & -9 \\
\hline & & & $\mathrm{t} / 2$ (JIS-A2号改) & 360 & 556 & 0.65 & - & $\mathrm{t} / 2$ & 95 & 6 \\
\hline \multirow{2}{*}{$\begin{array}{c}\text { 第 } 2 \text { シリーズ } \\
\text { (小形角棒の脆性破断) }\end{array}$} & \multirow{2}{*}{$\begin{array}{c}\text { 低䩚性・ t40 } \\
\text { (SN490) }\end{array}$} & \multirow{2}{*}{$\begin{array}{c}\text { 角棒 } \\
\mathrm{t} 40 \times \mathrm{B} 50 \\
\end{array}$} & t/4 (JIS-4号) & 325 & 555 & 0.59 & 19 & $\mathrm{t} / 4$ & 47 & 26 \\
\hline & & & $\mathrm{t} / 2$ (JIS-4号) & 300 & 553 & 0.54 & 20 & $\mathrm{t} / 2$ & 16 & 42 \\
\hline \multirow{2}{*}{$\begin{array}{c}\text { 第 } 3 \text { シリーズ } \\
\text { (小形丸棒の擬似脆性破断) }\end{array}$} & $\begin{array}{c}\text { 低勒性・故100 } \\
(\mathrm{SN} 490)\end{array}$ & \multirow{2}{*}{$\begin{array}{c}\text { 丸棒 } \\
\text { 直径 } \phi 14\end{array}$} & $\mathrm{t} / 4$ (JIS-4号) & 295 & 533 & 0.55 & 20 & $t / 4$ & 32 & 45 \\
\hline & $\begin{array}{l}\text { 高靭性 } \cdot \mathrm{t} 40 \\
(\mathrm{SN} 490)\end{array}$ & & $\mathrm{t} / 2$ (JIS-4号) & 333 & 536 & 0.62 & 23 & $\mathrm{t} / 2$ & 107 & 15 \\
\hline \multirow{3}{*}{$\begin{array}{c}\text { 第 } 4 \text { シリーズ } \\
\text { (小形溶接H梁の延性破断) }\end{array}$} & \multirow[t]{2}{*}{$\mathrm{HT} 600 \cdot \mathrm{tg}$} & $\begin{array}{l}\text { フランジ } \\
\text { (ソスカラップ) } \\
\mathrm{t} 9 \times \mathrm{B} 100 \\
\end{array}$ & 全厚 (JIS-5号) & 431 & 587 & 0.73 & 14 & $\begin{array}{c}t / 2 \\
(1 / 2 \text { サフォ } \\
\text { X) }\end{array}$ & 150 & -60 \\
\hline & & $\begin{array}{c}\text { フランジ } \\
\text { (劝ラップ } \\
\mathrm{t} 9 \times \mathrm{B} 100 \\
\end{array}$ & 全厚 (JIS-5号) & 445 & 610 & 0.73 & 12 & $\begin{array}{c}t / 2 \\
(1 / 2+\text { オサイ } \\
\text { X) }\end{array}$ & 120 & -50 \\
\hline & $\mathrm{SM} 490 \cdot \mathrm{t} 9$ & $\begin{array}{l}\text { フランジ } \\
\mathrm{t} 9 \times \mathrm{B} 100\end{array}$ & 全厚 (JIS-5号) & 334 & 522 & 0.64 & 17 & - & - & - \\
\hline
\end{tabular}




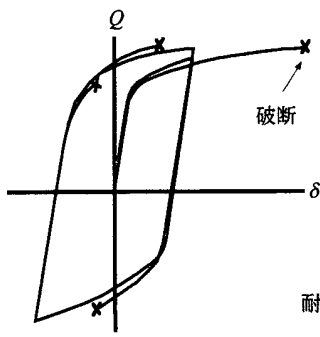

(a) 脆性破断

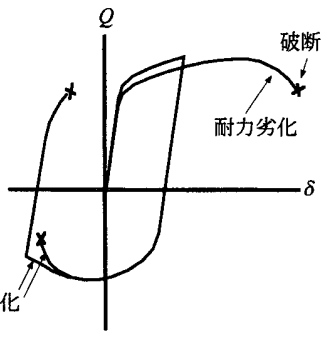

（b）擬似脆性破断之延性破断

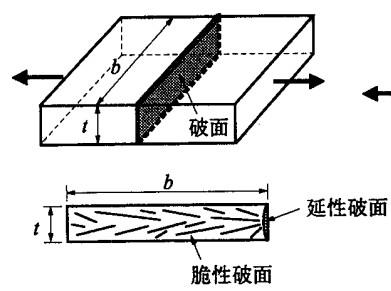

(a) 脆性破断

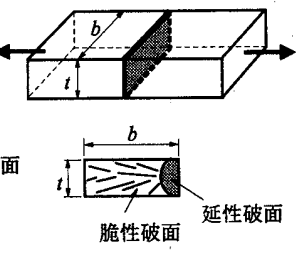

(b) 擬似脆性破断

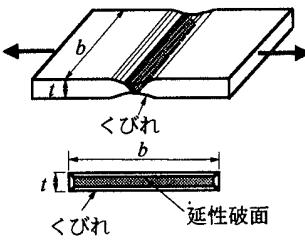

(c) 延性破断

図一４＼cjkstart荷重一変形曲線による破断モードの分類

図一5＼cjkstart破面による破断モードの分類

表一 3 大形 Box 梁の脆性破断

\begin{tabular}{|c|c|c|c|c|c|c|c|c|c|c|c|c|c|}
\hline 材料 & 載荷方法 & 試験体 & $\begin{array}{l}Q p \\
\text { (tonf) }\end{array}$ & $\begin{array}{l}\delta p \\
(\mathrm{~mm})\end{array}$ & $\begin{array}{c}Q f \\
\text { (tonf) }\end{array}$ & $\begin{array}{l}Q \max \\
\text { (tonf) }\end{array}$ & $\begin{array}{l}\text { 延性き裂 } \\
\text { 深さ }(\mathrm{mm})\end{array}$ & $\begin{array}{l}\text { 破断 } \\
\text { モ一ド }\end{array}$ & 破断温 & $\mu p$ & $\eta p$ & $N f$ & 回帰 \\
\hline \multirow{7}{*}{ 低勒性 } & \multirow[t]{2}{*}{ 単調 } & LM1 & 78.3 & 12.0 & 125 & 125 & $\begin{array}{r}1.6 \\
\end{array}$ & \multirow{7}{*}{ 脆性 } & -0.6 & 12.0 & 12.0 & 1.0 & \multirow{7}{*}{$\eta p M=11.8$} \\
\hline & & LM2 & 78.6 & 11.9 & 128 & 128 & 1.5 & & -0.3 & 13.2 & 13.2 & 1.0 & \\
\hline & \multirow{5}{*}{ 繰返し } & LC1 & 79.7 & 11.9 & -97 & 122 & 0.2 & & 0.0 & 8.4 & 12.3 & 1.5 & \\
\hline & & LC2 & 78.5 & 12.0 & -108 & 109 & 1.2 & & -0.7 & 5.3 & 11.2 & 2.1 & \\
\hline & & LC3 & 78.9 & 11.8 & -109 & -113 & 1.4 & & 0.9 & 2.6 & 27.4 & 10.6 & \\
\hline & & LC4 & 78.9 & 12.0 & -102 & -106 & 2.4 & & 0.0 & 1.4 & 49.6 & 34.8 & \\
\hline & & LC5 & 78.8 & 11.9 & 88 & -97 & 3.7 & & -0.7 & 0.8 & 66.4 & 84.6 & \\
\hline \multirow{5}{*}{ 高勒性 } & \multirow{5}{*}{ 繰返し } & $\mathrm{HCl}$ & 80.8 & 12.2 & -92 & 123 & 0.4 & \multirow{5}{*}{ 脆性 } & -1.9 & 15.2 & 19.0 & 1.3 & \multirow[t]{5}{*}{$\eta p M=26.8$} \\
\hline & & $\mathrm{HC} 2$ & 80.1 & 12.1 & -123 & -130 & 2.9 & & 0.5 & 12.5 & 34.5 & 2.8 & \\
\hline & & $\mathrm{HC} 3$ & 80.5 & 12.1 & 127 & -129 & 1.5 & & 2.4 & 9.8 & 44.5 & 4.5 & \\
\hline & & $\mathrm{HC} 4$ & 80.3 & 12.0 & -112 & -118 & 2.9 & & 0.9 & 4.6 & 65.7 & 14.4 & \\
\hline & & HC5 & 80.4 & 12.2 & 94 & 99 & 3.4 & & 0.6 & 1.3 & 133.8 & 104.7 & \\
\hline
\end{tabular}

となるので,

$$
S=\sum_{i=1}^{m} \Delta y_{i}^{2}
$$

を最小化する $\eta_{p M}$ を求めることになる。 $m$ は同一グループのサンプ ル数である。

上で回帰された $\eta_{p M}$ 值を用いたときの誤差 $e_{r}$ の範囲（最小值 一最大值）と平均䛊差は次のようになる。

$$
\begin{aligned}
& \min _{i}\left\{\left|\Delta y_{i}\right|\right\} \leq e_{r} \leq \max _{i}\left\{\left|\Delta y_{i}\right|\right\} \\
& \operatorname{ave}\left(e_{r}\right)=\frac{1}{m} \sum_{i=1}^{m}\left|\Delta y_{i}\right|
\end{aligned}
$$

\section{4 検証の結果}

\section{1 第 1 シリーズ : 大形 Box 梁の脆性破断}

第 1 シリーズの実験データを表一 3 にまとめてある。表の右端闌 は回㷌分析によって得られた $\eta_{p M}$ 值および $\eta_{p}$ の評価誤差である。 $\eta_{p M}$ で基準化された塑性率振幅 $\mu_{p} / \eta_{p M}$ に対する同じく基準化され た累積塑性率の推定值 $\eta_{p} / \eta_{p M}$ の関係をプロットし，(11)式と比較し たのが図一6である。

この(11)式は，もともとこの実験シリーズのうち低靶性材のデータ から回帰されたものであるので, 実験データとの一致性は高く, $\eta_{p} /$ $\eta_{p M}$ の評価值の平均誤差は僅か $7 \%$ である。高勒性材については, 平 均誤差が $21 \%$ でやや精度が落ちているが，脆性破断現象のばらつき を考えると工学的には満足できる信頼性をもっている。

この第 1 シリーズより，脆性破断までの振幅と累積変形の関係が 鋼材の種類によらないという「破断履歴の相似則」の 1 面が示され

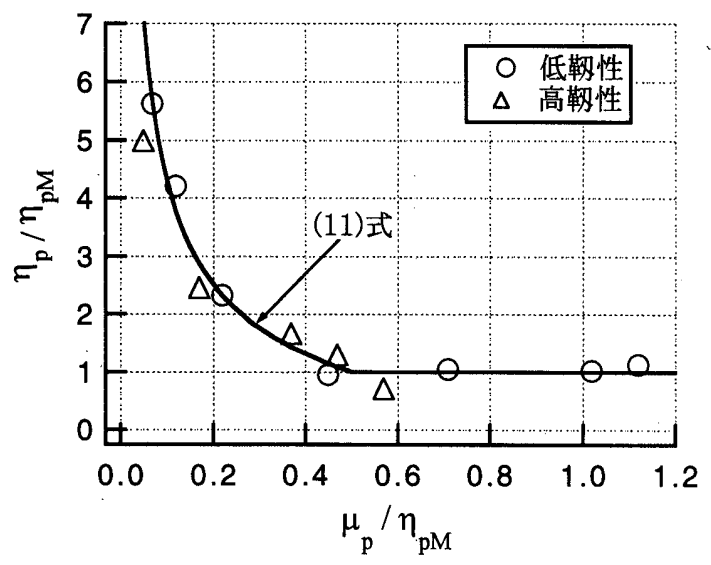

図ー6 第 1 シリーズの振幅と累樍の関係

たと考えられる。また，脆性破壊は応力支配型と考えられているが， 降伏応力を超えた塑性変形過程で生じる脆性破壊では, 塑性変形を 用いて脆性破断のクライテリアを立てることができ, 応力は従属要 因としてその中に折り込まれると言える。

\section{2 第 2 シリーズ：小形角棒の脆性破断}

同様に，第 2 シリーズの実験デー夕と回帰分析結果を表一 4 にま とめ, 塑性率振幅と累積塑性率の関係を図一 7 に示してある。第 2 シリーズでは, 単調載荷と繰返し載荷で破断モードが異なっている。 そこで，単調載荷のデー夕（3 個）を含めた場合と除いた場合の2

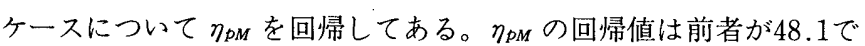
後者が 43.8 となる。これは擬似脆性破断では破断までの変形能力が 脆性破断よりも大きい傾向があることを示している。単調載荷での 
表一 4 小形角棒の脆性破断

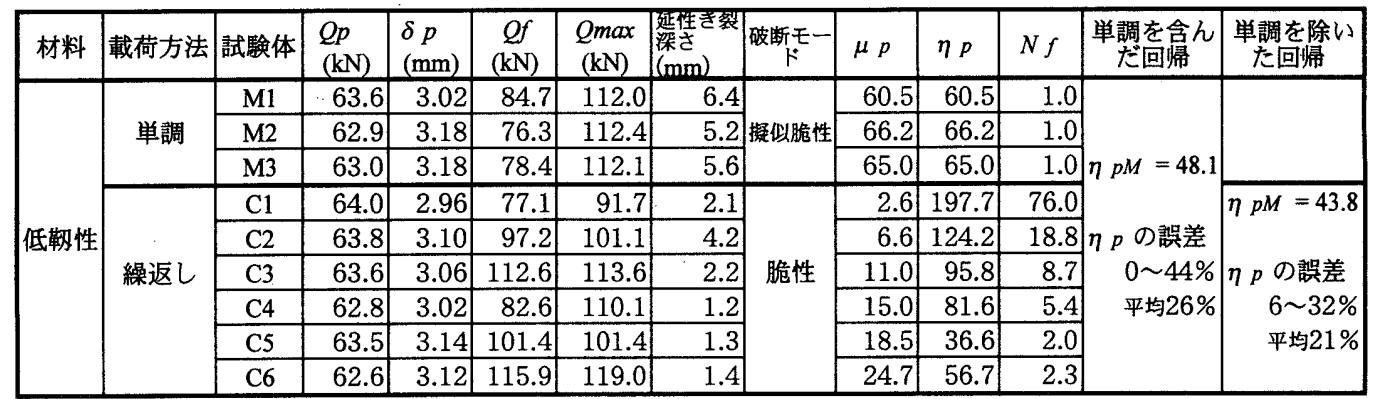

擬似脆性破断を除いて繰返しによる脆性破断だけを考慮した場合, $\eta_{p} / \eta_{p M}$ の評価值の平均誤差は $21 \%$ であり, 満足できる精度である。

この第 2 シリーズを第 1 シリーズとあわせると, 相似性の法則が 寸法が異なっても成立することが示されたと考えられる。

\section{3 第 3 シリーズ：小形丸棒の擬似脆性破断}

第 3 シリーズの実験データと回帰分析結果を表一 5 にまとめてあ る。軸方向繰返し載荷については, 引張から始める場合 (先引張) と圧縮から始める場合 (先圧縮) があり，両者の $\eta_{p}$ は異なる。この ような軸力の繰返し載荷を曲げの繰返し載荷と同等に扱うには，先 引張と先圧縮のうち $\eta_{p}$ 值の小さいほうを採る必要がある。表一 5 では $\eta_{p}$ の大きいほうを網掛けし，これを除いて $\eta_{p M}$ 值を回帰して

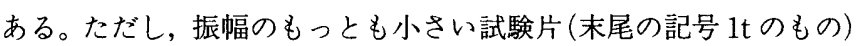
は先引張しか実施していないが, $N_{f}$ が100程度あり, 先圧縮との差 がほとんどないと考えられるのでそのまま採用した。

$\eta_{p} / \eta_{p M}$ の評価值の平均誤差を 4 グループについて見ると， $10 \%$ 〜 $18 \%$ の範囲にあり，「破断履歴の相似則」が擬似脆性破断にも適用 できることがわかる。塑性率振幅と累積塑性率の関係を示した図 -8(a)，(b)より，それぞれ，振幅と累積の関係に及ぼすノッチ形状 と材料䩒性の影響がないことが認められ，相似則の成立性が確認で きる。

\section{4 第 4 シリーズ：小形溶接 $\mathrm{H}$ 梁の延性破断}

第 4 シリーズの実験デー夕と回㷌分析結果を表一 6 にまとめてあ る。単調載荷で局部座屈したものは回帰分析で除いてある。 $\eta_{p} / \eta_{p M}$ の評価值の平均誤差を 6 グループについて見ると $13 \%$ 25\%の範囲 にあり，やや精度が落ちるグループがあるが，「破断履歴の相似則」 が延性破断にも適用できると見てよいであろう。塑性率振幅と累積 塑性率の関係を HT600と SM490についてそれぞれ図一9(a)，(b)に 示す。これより，振幅と累積の関係に及ぼす溶接条件の影響がない ことが認められ，相似則の成立性が確認できる。

\section{5 結 論}

今まで仮説として扱われてきた「破断履歴の相似則」を 4 シリー ズの独立した実験デー夕を用いて検証した。その結果, 本文(9), (10), (11)式が, 材料や部材サイズ, 溶接の条件にかかわらず成立する相似 性が実証された。すなわち, 塑性率振幅 $\mu_{p}$, 破断までの累積塑性率 $\eta_{p}$, 破断までの修正サイクル数 $N_{f}$ の関係が単調載荷での破断塑性 率 $\eta_{p M}$ を基準值に用いると単一の曲線で表される。しかも，脆性破 断だけでなく，耐力劣化を伴う擬似脆性破断および延性破断に対し ても同程度の精度でこの式を適用できることが明らかとなった。た

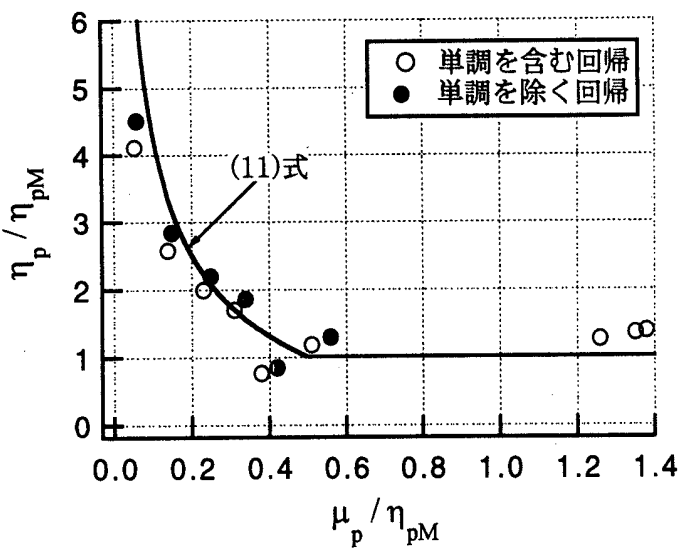

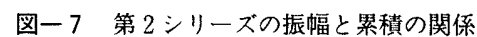

だし，単調載荷と繰返し載荷で破断モードが異なる場合は別個に扱 う必要がある。

この「破断履歴の相似則」を用いると, ある一つの変位振幅にお ける破断までの累積塑性変形が実験で得られれば，他の任意の振幅 における破断までの累積塑性変形を推定することができるので, 破 断を考慮した耐震設計への展望が開けるものと期待される。

本研究は「破断履歴の相似則」を実験データに基づいて実証する ことにおいて所期の成果がおさめられたが，理論的根拠については 今後の研究に待ちたい。また，地震応答はランダムな振幅となるの で，本研究で得られた一定振幅での破断条件式を変動振幅に適用で きるように検討を進める必要があろう。

\section{謝 辞}

この研究にあたって，文部省科学研究費基盤研究 $\mathrm{A}$ 「高層建築鉄 骨の脆性破壊の防止技術に関する研究」（研究代表者：桑村（仁）の 補助を受けた。

\section{参考文献}

1) 高木直人, 桑村 仁：酎力劣化を伴う擬似脆性破壊に及ぼす変形履歴の影 響，日本建築学会関東支部研究報告集，No.24，pp.93-96，2000.2

2）一戸康生,桑村 仁：鉄骨の脆性破断に及ほす繰返し変位振幅の影響一鉄 骨破断に関する研究 その 3 -, 日本建築学会構造系論文集, No. 534, pp. 145-151，2000.8

3）伊山 潤, 鈴木孝彦, 桑村 仁：鋼部材の繰返し履歴曲線と単調載荷曲線 の関係(その 1 破壊する場合), 日本建築学会関東支部研究報告集, No. 22 , pp.85-88, 1998.2

4）松井康治, 稲葉雄一郎, 伊山 潤. 桑村 仁：鉄骨部材の脆性破断変形能 
表一 5 小形丸棒の擬似脆性破断

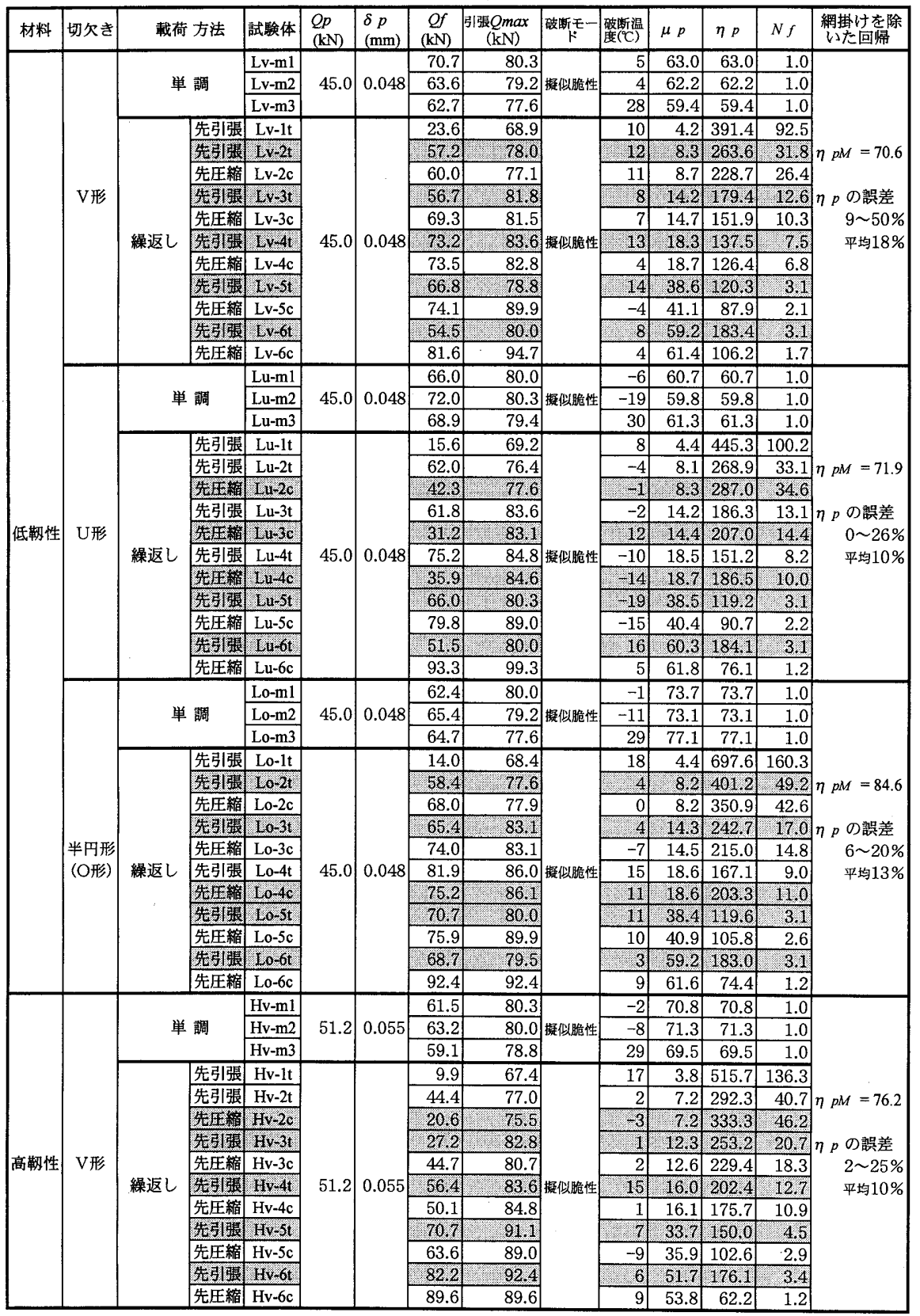

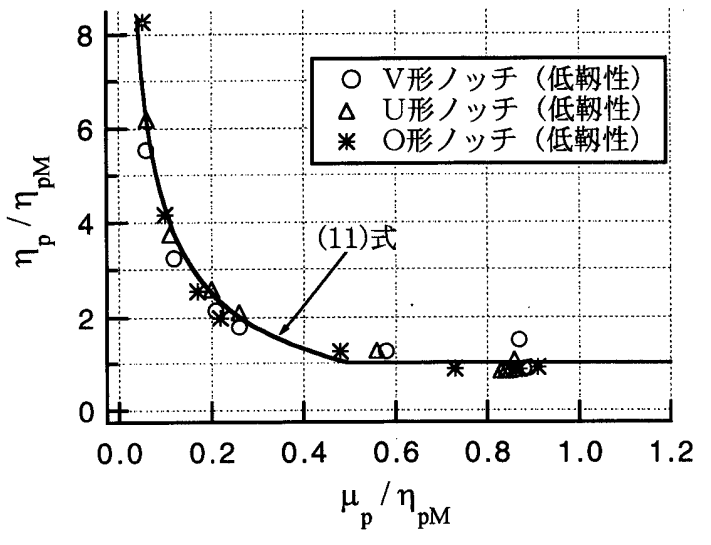

(a) ノッチ形状の影響

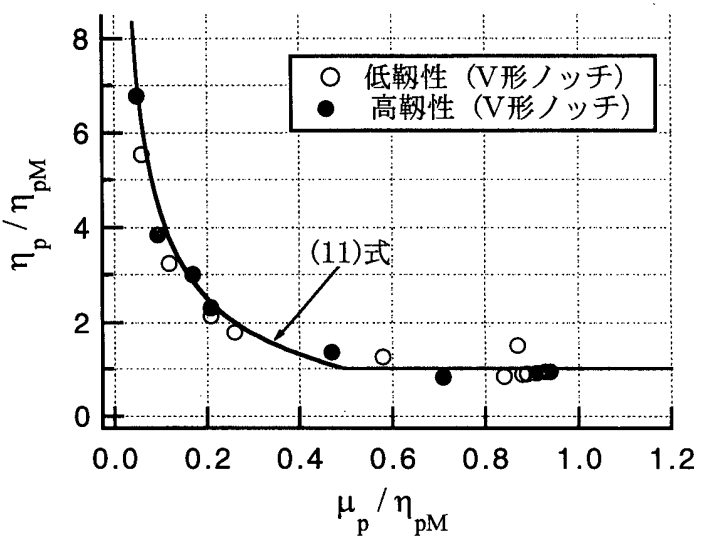

（b）材料靶性の影響

図一 8 第 3 シリーズの振幅と累積の関係 
表一 6 小形溶接 $\mathrm{H}$ 梁の延性破断

\begin{tabular}{|c|c|c|c|c|c|c|c|c|c|c|c|c|}
\hline 材料 & 溶接 & 載荷方法 & 試験体 & $\begin{array}{l}Q p \\
\text { (tonf) }\end{array}$ & $\begin{array}{l}\delta p \\
(\mathrm{~cm})\end{array}$ & $\begin{array}{c}f \\
\text { (tonf) }\end{array}$ & $\begin{array}{l}Q \max \\
\text { (tonf) }\end{array}$ & 破断モード & $\mu p$ & $\eta p$ & $N f$ & 回帰 \\
\hline \multirow{17}{*}{ HT600 } & \multirow{5}{*}{$\begin{array}{l}\text { ハンスカラップ } \\
\text { 下向き溶接 }\end{array}$} & 単調. & HT-NS-F-M & \multirow{5}{*}{9.23} & \multirow{5}{*}{1.58} & - & 12.7 & 局部座屈 & $\overline{-}$ & - & - & \multirow{5}{*}{$\begin{array}{r}\eta p M=16.9 \\
\eta p \text { の誤差 : } \\
12 \sim 43 \% \\
\text { 平均 } 25 \%\end{array}$} \\
\hline & & \multirow{4}{*}{ 繰返し } & HT-NS-F-3 & & & 7.86 & 11.1 & \multirow{4}{*}{$\begin{array}{l}\text { 延性破断 } \\
\text { (フランジ緣) }\end{array}$} & 1.35 & 107.6 & 79.6 & \\
\hline & & & HT-NS-F-4 & & & 7.92 & 11.9 & & 1.86 & 53.5 & 28.7 & \\
\hline & & & HT-NS-F-5 & & & 7.62 & 12.0 & & 2.62 & 58.4 & 23.3 & \\
\hline & & & HT-NS-F-7 & & & 6.66 & 12.9 & & 4.18 & 20.1 & 4.8 & \\
\hline & \multirow{4}{*}{$\begin{array}{l}\text { ハンスカラップ } \\
\text { 立向き溶接 }\end{array}$} & 単調 & HT-NS-V-M & \multirow{4}{*}{9.09} & \multirow{4}{*}{1.51} & - & 12.4 & 局部座屈 & - & - & - & \multirow{4}{*}{$\begin{array}{r}\eta p M=19.4 \\
\eta p \text { の誤差 : } \\
9 \sim 22 \% \\
\text { 平均 } 18 \%\end{array}$} \\
\hline & & \multirow{3}{*}{ 繰返し } & HT-NS-V-3 & & & 5.00 & 11.1 & \multirow{3}{*}{$\begin{array}{c}\text { 延性破断 } \\
\text { (フランジ槉) }\end{array}$} & 1.22 & 143.8 & 117.9 & \\
\hline & & & HT-NS-V-5 & & & 7.30 & 12.1 & & 2.75 & 50.5 & 18.4 & \\
\hline & & & HT-NS-V-7 & & & 2.40 & 12.7 & & 4.33 & 40.4 & 9.3 & \\
\hline & \multirow{4}{*}{$\begin{array}{c}\text { スカラップ有り } \\
\text { 下向き溶接 }\end{array}$} & 単調 & HT-SC-F-M & \multirow{4}{*}{8.75} & \multirow{4}{*}{1.52} & 7.92 & 11.2 & \multirow{4}{*}{$\begin{array}{c}\text { 延性破断 } \\
(\text { スカラップ底) }\end{array}$} & 3.38 & 3.38 & 1.0 & $\eta p M=5.9$ \\
\hline & & \multirow{3}{*}{ 繰返し } & HT-SC-F-2 & & & 4.86 & 9.5 & & 0.49 & 30.7 & 63.2 & $\eta p$ の誤差 : \\
\hline & & & HT-SC-F-3 & & & 8.14 & 10.8 & & 1.12 & 14.3 & 12.8 & $5 \sim 43 \%$ \\
\hline & & & HT-SC-F-4 & & & 5.32 & 11.6 & & 1.95 & 10.6 & 5.4 & 平均 $17 \%$ \\
\hline & \multirow{4}{*}{$\begin{array}{c}\text { スカラップ有り } \\
\text { 下向き溶接 } \\
\text { 止端R処理 }\end{array}$} & 単調 & HT-SCF-F-M & \multirow{4}{*}{8.86} & \multirow{4}{*}{1.61} & 2.62 & 10.9 & \multirow{4}{*}{$\begin{array}{c}\text { 延性破断 } \\
(\text { スカラップ底) }\end{array}$} & 4.13 & 4.13 & 1.0 & \multirow{4}{*}{$\begin{array}{r}\eta p M=5.7 \\
\eta p \text { の誤差 : } \\
4 \sim 28 \% \\
\text { 平均 } 18 \%\end{array}$} \\
\hline & & \multirow{3}{*}{ 繰返し } & HT-SCF-F-2 & & & 5.48 & 9.6 & & 0.52 & 20.4 & 39.5 & \\
\hline & & & HT-SCF-F-3 & & & 7.02 & 10.9 & & 1.03 & 18.1 & 17.5 & \\
\hline & & & HT-SCF-F-4 & & & 7.54 & 11.6 & & 1.84 & 9.7 & 5.3 & \\
\hline \multirow{8}{*}{ SM490 } & \multirow{4}{*}{$\begin{array}{c}\text { ハンスカラップ } \\
\text { 下向き溶接 }\end{array}$} & 単調 & SM-NS-F-M & \multirow{4}{*}{7.62} & \multirow{4}{*}{1.22} & - & $>12.0$ & 局部座座 & - & - & - & \multirow{4}{*}{$\begin{array}{r}\eta p M=44.5 \\
\eta p \text { の誤差 : } \\
5 \sim 17 \% \\
\text { 平均 } 13 \%\end{array}$} \\
\hline & & \multirow{3}{*}{ 繰返し } & SM-NS-F-5 & & & 4.74 & 10.4 & 延性破断 & 2.87 & 250.4 & 87.2 & \\
\hline & & & SM-NS-F-7 & & & 5.56 & 10.5 & (フランジ緣) & 3.99 & 244.5 & 61.3 & \\
\hline & & & SM-NS-F-9 & & & 4.94 & 10.2 & & 5.44 & 138.2 & 25.4 & \\
\hline & & 単調 & SM-SC-F-M & & & 2.06 & 10.4 & & 11.20 & 11.2 & 1.0 & $\eta p M=14.9$ \\
\hline & スカラップ有り & & SM-SC-F-3 & 7.35 & 1.28 & 5.78 & 8.9 & 延性破断 & 1.05 & 108.2 & 102.9 & $\eta p$ の誤差 : \\
\hline & & 繰返し & SM-SC-F-5 & & & 3.24 & 9.6 & (スカラッブ底 $)$ & 2.46 & 31.8 & 12.9 & $6 \sim 30 \%$ \\
\hline & & & SM-SC-F-7 & & & 4.68 & 10.1 & & 3.97 & 27.5 & 6.9 & 平均 $22 \%$ \\
\hline
\end{tabular}

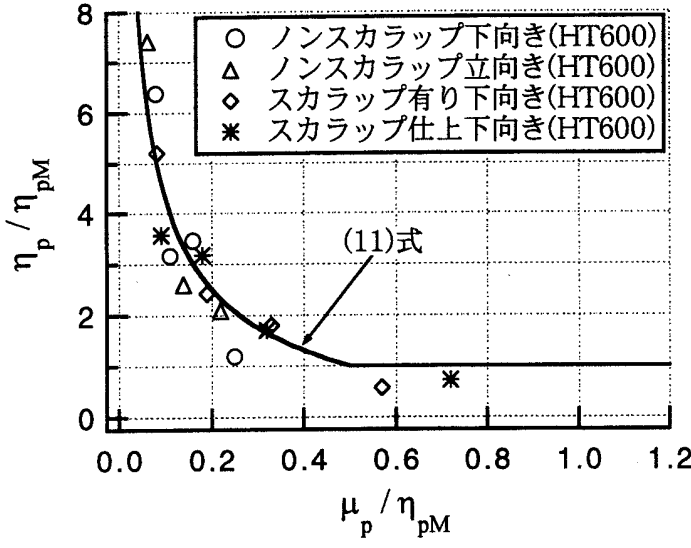

(a) HT600における溶接条件の影響

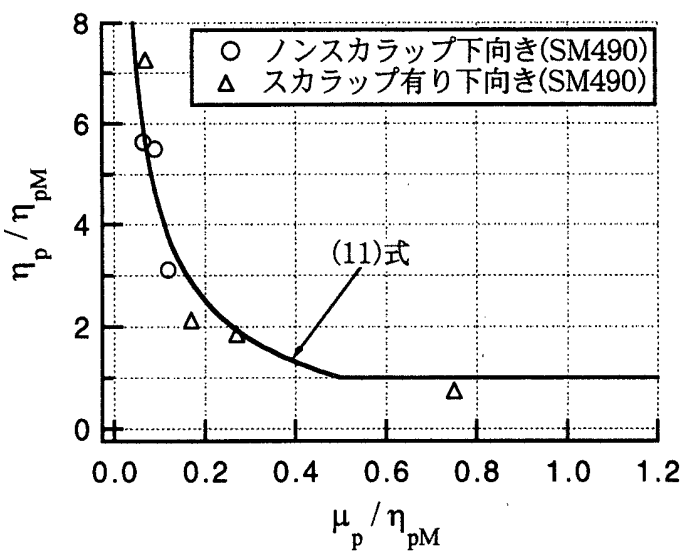

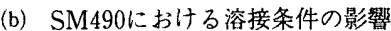

図ー9 第 4 シリーズの振幅と累積の関係

力とUずみ能力，日本建築学会関東支部研究報告集，No.9，pp.33-36， 1999.2

5）桑村 仁, 伊山 潤, 松井康治：鉄骨の脆性破断に及ぼす材料靶性と板厚 の影響 一鉄骨破断に関する研究 そのI-，日本建築学会構造系論文 集, No. 525, pp.109-116, 1999.11

6）桑村 仁，高木直人，松井康治：鉄骨の脆性破断に及ぼす溶接入熱の影響 一鉄骨破断に関する研究 その 2 - , 日本建築学会構造系論文集, No. 531, pp.157-164, 2000.5

7）桑村 仁：鉄骨の脆性破断を防止する耐震設計法試案（その1。デザイ ン・スキーム), 日本建築学会関東支部研究報告集, No. 27, pp.105-108,
2000.2

8）桑村 仁, 高木直人：鉄骨の脆性破断を防止する䩂震設計法試案(その 2 . フィージビリティ), 日本建築学会関東支部研究報告集, No. $28, \mathrm{pp}$ $109-112,2000.2$

9）桑村 仁：鉄骨の脆性破断に対する当面の对策技術, 日本建築学会大会パ ネルディスカッション『鉄骨の破断現象はどこまで解明されたか，当面の 対策技術』，pp.95-111，2000.9

（2000年11月28日原稿受理，2001年 5 月17日採用決定 